\title{
Analisis Kontribusi Pajak Daerah Terhadap Pendapatan Asli Daerah Kabupaten Sikka Tahun 2013-2017
}

\author{
Antonius Philipus Kurniawan Gheta \\ Universitas Nusa Nipa Maumere Flores
}

\begin{abstract}
This study aims to calculate the level of contribution, to analyze the growth rate oflocal tax revenues on the indigenous revenue of Sikka Regency from 2013 to 2017 and To know the extent of the tax acceptance rates $S$ ikka Regency period 2018 until 2022. . The research methods used in this study are descriptive research methods with a quantitative approach to getting a clearer and more detailed picture of a state based on the data or information that has been obtained. The results of the research obtained by the average regional tax contribution to the original revenue of S ikka Regency from 2013-2017 (5 years) by 14.27\%. These results indicate that the level of regional tax contributions to the indigenous revenue of $S$ ikka regency from 2013-2017 in the criteria of less co ntributing to the local revenue. The average rate of growth in S ikka District tax is 2013-2017, which amounted to 16.2\%. This shows that the local tax growth of $S$ ikka Regency is included in the less successful criteria. The results of the projected calculation of regional tax revenues for the next five years, 2018-2022 are expected to continue to increase annually. In 2018 predictions of $S$ ikka district tax revenues amounted to $R p$ 15,960,932,070.345. In 2019 the prediction of local tax revenues amounted to $R p$ 17,514,147,581.89 and in 2020 the predicted regional tax revenue of $R p$ 19,067,363,093.435. The regional tax prediction of $S$ ikka Regency in 2021 amounted to $R p 20,620,578,604.98$, while in 2022 the regional tax revenues of Sikka Regency were predicted Rp22,173,794,116.525
\end{abstract}

Keywords: regional tax contributions, local indigenous revenue

\section{Pendahuluan}

Realisasi pelaksanaan otonomi daerah memerlukan sumber-sumber penerimaan daerah yang diharapkan dan diupayakan dapat menjadi penyangga utama dalam membiayai kegiatan pembangunan di daerah. Menurut S iregar (2015:31) pendapatan asli daerah merupakan salah satu sumber penerimaan yang diperoleh daerah dari sumber-sumber di wilayahnya sendiri yang diambil berdasarkan Peraturan Daerah. Berdasarkan U ndang-Undang Nomor 23 tahun 
2014 tentang Pemerintahan Daerah, terdapat empat komponen penerimaan pendapatan asli daerah. Komponen-komponen tersebut antara lain pajak daerah, retribusi daerah, hasil pengelolaan kekayaan daerah yang dipisahkan, dan lain- lain pendapatan asli daerah yang disahkan.

Salah satu unsur pendapatan asli daera $\mathrm{h}$ adalah pajak daerah. Menurut Mardiasmo (Kamagi, dkk, 2016), pajak daerah adalah iuran wajib yang dilakukan oleh orang pribadi atau badan kepada daerah tanpa imbalan langsung yang seimbang, yang dapat dipaksakan berdasarkan peraturan perundang-undangan yang berlaku, yang digunakan untuk membiayai penyelenggaran daerah dan pembangunan daerah. Pajak daerah merupakan salah satu komponen pendapatan asli daerah yang memiliki prospek yang sangat baik untuk dikembangkan. Oleh karena itu, potensi pajak daerah harus dikelola secara secara baik dalam rangka optimalisasi dan usaha meningkatkan kontribusinya sebagai sumber pendapatan bagi daerah.

Terdapat beberapa jenis Pajak daerah yang dipungut dikabubaten Sikka. Berdasarkan PERDA No. 10 tahun 2011, terdapat delapan jenis pajak daerah yang terdiri dari pajak hotel, pajak restoran, pajak hiburan, pajak reklame, pajak penerangan jalan, pajak mineral bukan logam dan batuan, pajak parkir, dan pajak air tanah. Khusus untuk pajak bumi dan bangunan perdesaan dan perkotaa $\mathrm{n}$ di atur dalam PERDA No. 8 tahun 2012. Sedangkan bea perolehan hak atas tanah dan bangunan di atur dalam PERDA No. 2 tahun 2011. Jadi, pajak daerah yang dipungut di Kabupaten S ikka secara keseluruhan berjumlah sepuluh jenis pajak daerah. Berikut merupakan data target dan realisasi pajak daerah dan pendapatan asli daerah Kabupaten Sikka dari tahun 2013-2017 dapat di lihat tabel di bawah ini. 
Tabel 1. Target dan Realisasi Pajak Daerah Kabupaten Sikka Terhitung dari tahun $2013-2017$

\begin{tabular}{|l|l|l|l|}
\hline \multirow{2}{*}{ Tahun } & \multicolumn{3}{|c|}{ Pajak Daerah } \\
\cline { 2 - 4 } & Target (Rp & Realisasi & \\
\hline 2013 & 7.430 .885 .000 .00 & 8.526 .091 .731 .00 & 114,74 \\
\hline 2014 & 10.021 .068 .075 .00 & 9.511 .660 .055 .55 & 94,92 \\
\hline 2015 & 12.448 .409 .695 .00 & 11.608 .213 .126 .00 & 93,25 \\
\hline 2016 & 19.469 .721 .617 .00 & 11.624 .926 .899 .00 & 59,71 \\
\hline 2017 & 30.445 .189 .100 .00 & 15.235 .535 .867 .00 & 50,04 \\
\hline
\end{tabular}

Sumber : Badan Pendapatan Daerah Kabupaten Sikka

Berdasarkan tabel 1 dapat di lihat bahwa presentase pajak daerah dari tahun ke tahun mengalami penurunan. Presentase pajak daerah tertinggi pada tahun 2013 sebesaar $114,74 \%$ dan presentase terendahnya pada tahun 2017 yakni sebesar $50,04 \%$.

Tabel 2. Target dan Realisasi Pendapatan Asli Daerah Kabupaten Sikka terhitung dari tahun 2013-2017

\begin{tabular}{|l|l|l|l|}
\hline \multirow{2}{*}{ Tahun } & \multicolumn{3}{|c|}{ Pendapatan Asli Daerah } \\
\cline { 2 - 4 } & \multicolumn{1}{|c|}{ Target (Rp) } & Realisasi & \\
\hline 2013 & 47.340 .132 .736 .00 & 50.257 .084 .172 .90 & 106,16 \\
\hline 2014 & 62.461 .378 .889 .00 & 78.356 .674 .459 .86 & 125,45 \\
\hline 2015 & 78.754 .102 .822 .00 & $78.096 .258 .303 . .50$ & 99,16 \\
\hline 2016 & 98.858 .138 .792 .00 & 80.269 .749 .570 .99 & 81,20 \\
\hline 2017 & 142.894 .813 .580 .00 & 118.176 .975 .236 .17 & 82.70 \\
\hline
\end{tabular}

Sumber : Badan Pendapatan Asli Daerah Kabupaten Sikka

Berdasarkan tabel 2 diatas dapat dilihat bahwa presentase penerimaan pendapatan asli daerah Kabupaten S ikka selama dua tahun yakni tahun 2013 dan 2014 selalu melampaui target yang di tetapkan, yakni sebesar 106,16\% dan 125,45\%. Namun, dalam 3 tahun terakhir, yakni dari tahun 2015, 2016, dan 2017 presentase penerimaan $\mathrm{P} A D$ belum memenuhi target yang telah ditetapkan. 
Realisasi Penerimaan P AD tahun 2015 sebesar 99,16\%, tahun 2016 sebesar $81,20 \%$ dan $82,70 \%$ pada tahun 2017 .

Dari data yang ditampilkan dari kedua tabel diatas dapat disimpulkan bahwa Pemerintah Daerah (Badan Pendapatan Daerah Kabupaten Sikka) belum maksimal dalam melakukan pemungutan pajak daerah, terutama dari tahun 2015 hingga 2017 yang realisasinya belum mencapai target. Hal ini, tentu berdampak pula pada realisasi PAD kabupaten S ikka yang mengalami penurunan selama tahun 2015-2017. Adapun kendala yang dihadapi oleh Badan Pendapatan Daerah Kabupaten $S$ ikka seperti masalah kualitas sumber daya manusia baik pemungut pajak maupun wajib pajak. Selain itu, dikare nakan minimnya kesadaran masyarakat (wajib pajak) untuk membayar pajak daerah.

Berdasarkan uraian di atas peneliti tertarik untuk melakukan penelitian dengan judul "Analisis Kontibusi Pajak Daerah Terhadap Pendapatan Asli Daerah Kabupaten S ikka Tahun 2013-2017'.

\section{Tinjauan Pustaka}

\section{Pendapatan Daerah}

Menurut pasal 285 Undang-undang No. 23 Tahun 2014 tentang Pemerintahan Daerah, pendapatan daerah adalah semua hak daerah yang diakui sebagai pengurang nilai kekayaan bersih dalam periode tahun anggaran yang bersangkutan. Pendapatan daerah memegang peranan yang sangat penting, karena melalui sektor ini dapat dilihat sejauh mana suatu daerah dapat menjalankan kegiatan pemerintahan dan pembangunan yang menjadi unsur rumah tangganya. Untuk meningkatkan jumlah pendapatan daerah pemerintah daerah harus mampu menggali sumber-sumber daya yang mampu memberikan kontribusi terhadap pendapatan daerah.

Menurut pasal 285 UU No. 23 Tahun 2014 tentang Pemerintahan Daerah sumber-sumber pendapatan daerah terdiri atas :

\section{Pendapatan Asli Daerah ( PAD )}

Pendapatan asli daerah adalah pendapatan yang diperoleh daerah yang dipungut berdasarkan peraturan daerah yang berlaku sesuai dengan 
perun- dang-undangan yang berlaku.

2. Pendapatan Transfer yang terdiri atas :

a) Transfer Pemerintah P usat yang meliputi :

1) Dana Perimbangan

Dana perimbangan merupakan sumber pendapatan daerah yang berasal dari AP BN untuk mendukung pelaksanaan kewenangan pemerintah Daerah dalam mencapai tujuan pemberian otonomi kepada daerah, yaituterutama peningkatan pelayanan dan kesejahteraan masyarakat yan g semakin baik. Dana perimbangan terdiri atas: Dana alokasi umum, Dana alokasi khusus dan Dana bagi hasil.

2) Dana Otonomi Khusus

Dana otonomi khusus adalah dana yang dialokasikan pemerintah pusat kepada daerah yang memiliki otonomi khusus sesuai denga $n$ ketentuan undang- undang mengenai otonomi khusus.

3) Dana Keistimewaan

Dana keistimewaan adalah dana yang dialokasikan oleh pemerintah pusat kepada daerah istimewa sesuai dengan ketentuan undang-undang mengenai keistimewaan.

4) Dana Desa

Dana desa adalah da na yang dialokasikan oleh pemerintah pusat untuk mendanai penyelenggaraan pemerintahan, pelaksanaan pembangunan, dan pembinaan kemasyarakatan, serta pemberdayaan masyarakat desa berdasarkan kewenangan dan kebutuhan desa sesuai ketentuan undang - undang mengenai desa.

b) Transfer Antar Daerah yang meliputi :

1) Pendapatan Bagi Hasil

Pendapatan bagi hasil merupakan dana yang dialokasikan kepada daerah lain berdasarkan angka persentase tertentu sesuai dengan peraturan perundang-undangan. 


\section{2) Bantuan Keuangan}

Bantuan keuangan adalah dana yang diberikan oleh suatu daerah kepada daerah lainnya baik dalam rangka kerja sama daerah maupun untuk tujuan tertentu.

\section{Lain-lain Pendapatan Daerah yang Sah}

Lain- lain pendapatan daerah yang sah merupakan seluruh pendapatan daerah selain pendapatan asli daerah dan pendapatan transfer, yang meliputi hibah, dana darurat, dan lain - lain pendapatan sesuai dengan peraturan perundang - undangan yang berlaku.

\section{Pendapatan Asli Daerah}

Menurut Undang- undang No. 33 tahun 2004 tentang Perimbangan Keuangan Antara Pemerintah P usat dan Pemerintahan Daerah, Pendapatan Asli Daerah ( PAD ) adalah penerimaan yang diperoleh dari sumber - sumber dalam wilayahnya sendiri yang di pungut berdasarkan Peraturan Daerah yang sesuai dengan peraturan perundang - undangan yang berlaku.

Pendapatan Asli Daerah menurut Anggoro (2017:18) adalah pendapatan yang diperoleh pemerintah daerah atas pelaksanaan kegiatan pemerintahan dan pelayanan kepada masyarakat, serta pemanfaatan sumber daya yang dimiliki oleh pemerintah daerah.

Menurut Warsito dalam Putra (2018:150), Pendapatan asli daerah (PAD) adalah pendapatan yang bersumber dan dipungut sendiri oleh pemerintah daerah. Sumber PAD terdiri dari pajak daerah, retribusi daerah, laba dari Badan Usaha Milik Daerah (BUMD), dan pendapatan asli daerah lainnya yang sah.

Dari beberapa pengertian diatas dapat disimpulkan bahwa, pendapatan asli daerah adalah pendapatan yang diperoleh dari sumber-sumber pendapatan daerah dan dikelola sendiri oleh pemerintah daerah yang bertujuan untuk memberikan keleluasaan kepada daerah dalam menggali sumber pendanaan dalam pelaksanaan kegiatan pemerintahan dan pelayanan kepada masyarakat. S umber pendapatan asli daerah terdiri dari Pajak daerah, Retribusi daerah, hasil pengelolaan kekayaan daerah yang dipisahkan, lain- lain PAD yang sah. 


\section{Sumber Pendapatan Asli Daerah}

Pendapatan asli daerah sangat diharapkan menjadi sumber utama dalam melaksanakan otonomi daerah yang mandiri, nyata dan bertanggungjawab serta meningkatan upaya pemberdayaan masyarakat unt uk mendorong pembangunan daerah.

Menurut Undang-undang Nomor 23 Tahun 2014, komponen pendapatan asli daerah terdiri atas :

1. Pajak Daerah

Pajak daerah yang selanjutnya disebut pajak adalah kontribusi wajib pajak kepada daerah yang terutang oleh pribadi atau badan yang bersifat memaksa berdasarkan undang-undang, dengan tidak mendapatkan imbalan secara langsung dengan digunakan untuk keperluan daerah bagi sebesar-besarnya kemakmuran rakyat.

2. Retribusi Daerah

Retribusi daerah yang selanjutnya disebut retribus i adalah pungutan daerah atas jasa atau perizinan tertentu yang khususnya disediakan dan atau diberikan oleh pemerintah untuk kepentingan orang pribadi atau badan.

3. Hasil pengelolaan kekayaan yang dipisahkan

Jenis-jenis hasil pengelolaan daerah yang dipisahkan terdiri dari bagian laba atas penyertaan modal baik perusahaan milik negara maupun perusahaan milik swasta atau kelompok usaha masyarakat.

4. Lain-lain pendapatan asli daerah yang sah

Lain - lain P AD yang sah terdiri atas hasil penjualan aset daerah, jasa giro, pendapatan bunga, keuntungan selisih nilai tukar rupiah terhadap mata uang asing, komisi, potongan, ataupun bentuk lain sebagai akibat dari penjualan barang atau jasa oleh daerah.

\section{Pengertian Pajak Daerah}

Pajak Daerah menurut Undang- undang No. 28 Tahun 2009 tentang Pajak Daerah dan Retribusi Daerah pengertian Pajak Daerah, yang selanjutnya disebut pajak, adalah kontribusi wajib kepada daerah yang terutang oleh orang pribadi atau 
badan yang bersifat memaksa berdasarkan undang- undang, dengan tidak mendapatkan imbalan secara langsung dan digunakan untuk keperluan daerah bagi sebesar-besarnya kemakmuran rakyat.

Siahaan dalam Putra (2018:171) mengemukakan bahwa pajak daerah adalah pajak yang ditetapkan oleh pe merintah daerah dengan peraturan daerah (perda), yang wewenang pungutannya dilaksanakan oleh pemerintah daerah dan hasilnya digunakan untuk membiayai pengeluaran pemerintah daerah dalam pelaksanaan penyelenggaraan pemerintah dan pembangunan didaerah

Mardiasmo dalam Putra (2018:171), menyatakan pajak daerah adalah iuran wajib yang dilakukan oleh orang pribadi atau badan kepada daerah tanpa imbalan langsung yang seimbang, yang dapat dilaksanakan berdasarkan peraturan perundang-undang yang berlaku yang digunakan untuk membiayai penyelenggaraan pemerintah daerah.

Dari beberapa defenisi diatas dapat disimpulkan bahwa, pajak daerah adalah iuran wajib kepada daerah yang terutang oleh pribadi atau badan sesuai dengan peraturan yang berlaku untuk melaksanakan penyele nggaraan pemerintahan daerah dan pembangunan daerah demi terwujudnya kesejahteraan masyarakat.

\section{Ciri-ciri Pajak Daerah}

Menurut Putra (2018:179) ciri-ciri pajak daerah sebagai berikut:

1. Dipungut oleh pemda berdasarkan kekuatan peraturan perundangundangan.

2. Pajak daerah hanya dipungut diwilayah administrasi yang dikuasainya.

3. Dapat dipaksakan, yakni apabila wajib pajak tidak memenuhi kewajiban pembayaran pajak daerah, yang bersangkutan dapat dipaksakan, yakni apabila wajib pajak tidak memenuhi kewajiban pembayaran pajak daerah, yang bersangkutan dapat dikenakan sanksi (pidana dan denda ).

4. Tidak terdapat hubungan langsung antara pemungutan pajak daerah dengan imbalan atau balas jasa secara perseorangan.

5. Hasil penerimaan pajak daerah disetor ke kas daerah untuk membiayai kegiatan pemerintahan daerah. 


\section{Fungsi Pajak Daerah}

Menurut Warsito (P utra:2018:175) fungsi pajak daerah dapat dibedakan menjadi dua fungsi utama yaitu sebagai berikut:

\section{Fungsi Penerimaan (Budgetair)}

Fungsi yang paling utama dari pajak daerah adalah untuk mengisi kas daerah. Fungsi ini disebut dengan fungsi Budgetair yang secara sederhana dapat diartikan sebagai suatu alat pemerintah daerah untuk dapat menghimpun dana dari masyarakat yang diperuntukan pada berbagai kepentingan pembiayaan pembangunan daerah.

\section{Fungsi Pengaturan (Regulerend)}

Fungsi lain dari pajak daerah adalah untuk mengatur atau regulerend. Dalam hal ini pajak daerah dapat dipergunakan oleh pemerintah daerah sebagai instrumen untuk mencapai tujuan-tujuan tertentu. Dalam hal ini pengenaan pajak daerah dapat dilakukan untuk memengaruhi tingkat konsumsi dari barang dan jasa tertentu.

\section{Prinsip-prinsip Pajak Daerah}

Suatu pajak daerah harus memenuhi beberapa prinsip umum, sehingga pemungutannya dapat dilaksanakan dengan efektif dan efisien. Berikut merupakan beberapa prinsip pajak daerah (P utra, 2018:177), antara lain sebagai berikut :

\section{Prinsip Keadilan (equity)}

Dalam prinsip ini ditekankan pentingnya keseimbangan berdasarkan kemampuan masing-masing subyek pajak daerah. Yang dimaksud keseimbangan atas kemampuan subyek pajak adalah dalam pemungutan pajak tidak ada diskriminasi diantara sesama wajib pajak yang memiliki kemampuan sama. Pemungutan pajak yang dilakukan terhadap semua subyek pajak harus sesuai dengan batas kemampuan masing- masing, sehingga setiap masyarakat yang dengan kemampuan yang sama dikenai pajak yang sama dan masyarakat yang memiliki kemampuan yang berbeda memberikan kontribusi yang berbeda sesuai 
dengan kemampuannya masing- masing.

\section{Prinsip Kepastian (certainty)}

Dalam prinsip ini ditekankan pentingnya kepastian, baik aparatur pemungut pajak maupun wajib pajak. Kepastian dibidang pajak daerah antara lain mencakup dasar hukum yang mengaturnya; kepastian mengenai subyek, obyek, tarif dan dasar pengenaannya; serta kepastian mengenai tata cara pemungutannya. Adanya kepastian yang menjamin setiap orang untuk tidak ragu-ragu dalam menjalankan kewajiban membayar pajak daerah, karena segala sesuatunya diatur secara jelas.

\section{Prinsip Kemudahan (convenience)}

Pentingnya saat dan waktu yang tepat bagi wajib pajak daerah dalam memenuhi kewajibannya. Pemungutan pajak daerah sebaiknya dilakukan pada saat wajib pajak daerah menerima penghasilan. Dalam hal ini negara tidak mungkin melakukan pemungutan pajak daerah jika masyarakat tidak mempunyai kekuatan untuk membayarnya. Bahkan daerah seharusnya memberikan kesempatan terlebih dahulu kepada masyarakat untuk memperoleh peningkatan pendapatan, dan setelah itu mereka layak memberikan kontribusi kepada daerah dalam bentuk pajak daerah.

\section{Prinsip Efisiensi (efficiency)}

Efisiensi menjadi sangat penting dalam pemungutan pajak dapat diartikan sebagai biaya yang dikeluarkan dalam melaksanakan pemungutan pajak tidak boleh lebih besar dari jumlah pajak yang dipungutnya. Dalam prinsip ini terkandung pengertian bahwa pemungutan pajak yang sebesar-besarnya dan biaya yang sebesarbesarnya.

\section{Unsur-unsur Pajak Daerah}

Menurut Putra (2018:178) unsur-unsur pajak daerah antara lain sebagai berikut : 


\section{Subjek Pajak Daerah}

Subjek pajak daerah adalah orang pribadi atau badan yang menurut ketentuan peraturan perundang - undangan perpajakan ditentukan untuk melakukan kewajiban untuk membayar atau terlibat dalam pemungutan pajak atau pemotong pajak tertentu, misalnya pegawai, pengusaha, dan perusahaan.

2. Objek Pajak Daerah

Objek pajak adalah segala sesuatu yang dapat dikenakan pajak daerah sesuai dengan peraturan perundang-undangan yang berlaku. Misalnya seperti hotel, restoran, kendaraan bermotor dan lain sebagainya.

\section{Tarif Pajak Daerah}

Tarif pajak daerah adalah besar kecilnya jumlah pajak yang harus dibayarkan sesuai dengan kepemilikan terhadap obyek pajak. Besarnya tarif definitif untuk pajak daerah ditetapkan dengan Peraturan Daerah, namun nilainya tidak boleh lebih dari tarif maksimum yang telah ditentukan dalam Undang Undang tentang Pajak Daerah dan Retribusi Daerah.

\section{Pendekatan Sistem Pe mungutan Pajak Daerah}

Menurut P utra (2018:193), terdapat dua pendekatan sistem pemungutan pajak daerah, yaitu:

\section{Self Assessment}

Self assessment adalah proses administrasi perpajakan daerah di mana wajib pajak diberi kesempatan untuk melakukan perhitungan sendiri terhadap obyek pajak daerah yang menjadi kewajibannya dan langsung melakukan penyetoran dengan S urat Setoran Pajak Daerah (SSPD) sert a melampirkan Surat Pemberitahuan Pajak Daerah (SP TPD).

\section{Official Assessment}

Official assessment adalah proses administrasi perpajakan daerah di mana wajib pajak daerah harus menyerahkan Surat Pemberihauan Pajak Daerah (SPTPD) sebagai bahan proses penetapan pajak daerah terutang dan wajib pajak diberi S urat Ketetapan Pajak Daerah (SKPD). 


\section{Jenis - jenis Pajak Daerah}

Jenis-jenis pajak daerah menurut UU No. 28 Tahun 2009 dibagi menjadi dua jenis yaitu sebagai berikut:

\section{Jenis Pajak Provinsi terdiri atas:}

\section{a. Pajak Kendaraan Bermotor}

Pajak kendaraan bermotor adalah pajak atas kepemilikan dan atau penguasaan kendaraan bermotor. Sedangkan kendaraan ermotor adalah semua kendaraan beroda beserta gandengannya yang digunakan di semua jenis jalan darat, dan digerakkan oleh peralatan teknik berupa motor atau peralatan lainnya yang berfungsi untuk mengubah suatu sumber daya energi tertentu menjadi tenaga gerak kendaraan bermotor yang bersangkutan, termasuk alatalat berat dan alatalat besar yang dalam operasinya menggunakan roda dan motor dan tidak melekat secara permanen serta kendaraan bermotor yang dioper asikan di air.

b. Bea Balik Nama Kendaraan Bermotor

Bea balik nama kendaraan bermotor adalah pajak atas penyerahan hak milik kendaraan bermotor sebagai akibat perjanjian dua pihak atau perbuatan sepihak atau keadaan yang terjadi karena jual beli, tukar menuka $r$, hibah, warisan, atau pemasukan ke dalam badan usaha.

c. Pajak Bahan Bakar Kendaraan Bermotor

Pajak bahan bakar kendaraan bermotor adalah pajak atas penggunaan bahan bakar kendaraan bermotor. Sedangkan bahan bakar kendaraan bermotor adalah semua jenis bahan bakar cair atau gas yang digunakan untuk kendaraan bermotor.

\section{d. Pajak Air Permukaan}

Pajak air p ermukaan adalah pajak atas pengambilan dan/atau pemanfaatan air permukaan. Sedangkan air permukaan adalah semua air yang terdapat pada permukaan tanah, tidak termasuk air laut, baik yang berada di laut maupun di darat.

e. Pajak Rokok

Pajak rokok adalah pungutan atas cukai rokok yang dipungut oleh 
Pemerintah.

2. Jenis Pajak Kabupaten / Kota terdiri atas:

a. Pajak Hotel

Pajak hotel adalah pajak atas pelayanan yang disediakan oleh hotel. Sedangkan hotel adalah fasilitas penyedia jasa penginapan/peristirahatan termasuk jasa terkait lainnya dengan dipungut bayaran, yang mencakup juga hotel, losmen, gubuk pariwisata, wisma pariwisata, pesanggrahan, rumah penginapan dan sejenisnya, serta rumah kos dengan jumlah kamar lebih dari

10 (sepuluh).

\section{b. Pajak Restoran}

Pajak restoran adalah pajak atas pelayanan yang disediakan oleh restoran. Sedangkan restoran adalah fasilitas penyedia makanan dan/atau minuman dengan dipungut bayaran, yang menc akup juga rumah makan, kafetaria, kantin, warung, bar, dan sejenisnya termasuk jasa boga/katering.

c. Pajak hiburan

Pajak hiburan adalah pajak atas penyelenggaraan hiburan. Sedangkan hiburan adalah semua jenis tontonan, pertunjukan, permainan, dan/atau keramaian yang dinikmati dengan dipungut bayaran.

d. Pajak Reklame

Pajak reklame adalah pajak atas penyelenggaraan reklame. Sedangkan reklame adalah benda, alat, perbuatan, atau media yang bentuk dan corak ragamnya dirancana untuk tujuan komersial memperkenalkan, menganjurkan, mempromosikan, atau untuk menarik perhatian umum terhadap barang, jasa, orang, atau badan, yang dapat dilihat, dibaca, didengar, dirasakan, dan/atau dinikmati oleh umum.

e. Pajak Penerangan Jalan

Pajak penerangan jalan adalah pajak atas penggunaan tenaga listrik, baik yang dihasilkan sendiri maupun diperoleh dari sumber lain.

f. Pajak Mineral Bukan Logam dan Batuan

Pajak mineral bukan logam dan batuan adalah pajak atas kegiatan 
pengambilan mineral bukan logam dan batuan, baik dari sumber alam di dalam dan/atau permukaan bumi untuk dimanfaatkan. Sedangkan mineral bukan logam dan batuan adalah mineral bukan logam dan batuan sebagaimana dimaksud di dalam peraturan perundang-undangan di bidang mineral dan batubara.

\section{g. Pajak Parkir}

Pajak parkir adalah pajak atas penyelenggaraan tempat parkir di luar badan jalan, baik yang disediakan berkaitan dengan pokok usaha maupun yang disediakan sebagai suatu usaha, termasuk penyediaan tempat penitipan kendaraan bermotor.

h. Pajak Air Tanah

Pajak air tanah adalah pajak atas pengambilan dan/atau pemanfaatan air tanah. Sedangkan air tanah adalah air yang terdapat dalam lapisan tanah atau batuan di bawah permukaan tanah.

i. Pajak Sarang Burung Walet

Pajak sarang burung walet adalah pajak atas kegiatan pengambilan dan/atau pengusahaan sarang burung walet. Sedangkan burung walet adalah satwa yang termasuk marga collocalia, yaitu collocalia fuchliap haga, collocalia maxina, collocalia esculanta, dan collocalia linchi.

j. Pajak Bumi dan Bangunan Perdesaan dan Perkotaan

Pajak Bumi dan Bangunan Perdesaan dan Perkotaan adalah pajak atas bumi dan/atau bangunan yang dimiliki, dikuasai, dan/atau dimanfaatkan oleh orang pribadi atau Badan, kecuali kawasan yang digunakan untuk kegiatan usaha perkebunan, perhutanan, dan pertambangan.

k. Bea Perolehan Hak Atas Tanah dan Bangunan

Bea perolehan hak atas tanah dan bangunan adalah pajak atas perolehan hak atas tanah dan/atau bangunan.

\section{Kerangka Pemikiran}

Keuangan daerah pada dasarnya meliputi penerimaan dan pengeluaran pemerintah daerah. Dalam hal penerimaan daerah terdapat pendapatan asli 
daerah yang dipengaruhi oleh pajak daerah, retribusi daerah, hasil pengelolaan kekayaan daerah yang dipisahkan, dan lain- lain pendapatan asli daerah yang sah.

Dalam penelitian ini, peneliti bermaksud menganalisis laju pertumbuhan pajak daerah serta menganalisis kontribusi pajak daerah terhadap pendapatan asli daerah Kabupaten S ikka tahun 2013 sampai dengan tahun 2017. Pendapatan asli daerah (PAD) merupakan hal yang sangat penting karena dapat dijadikan sebagai pembiayaan pemerintah daerah dalam melaksanakan tugasnya serta dapat digunakan dalam pembangunan daerah.

Penelitian variabel pajak daerah dan pendapatan asli daerah mengacu pada penelitian Mulyana Utami, dkk (2018). Penelitian ini menggunakan data laporan target dan realisasi pendapatan asli daerah $\mathrm{K}$ abupaten $\mathrm{S}$ ikka tahun 2013-2017.

Berdasarkan uarian diatas, maka kerangka pemikiran dapat digambarkan sebagai berikut:

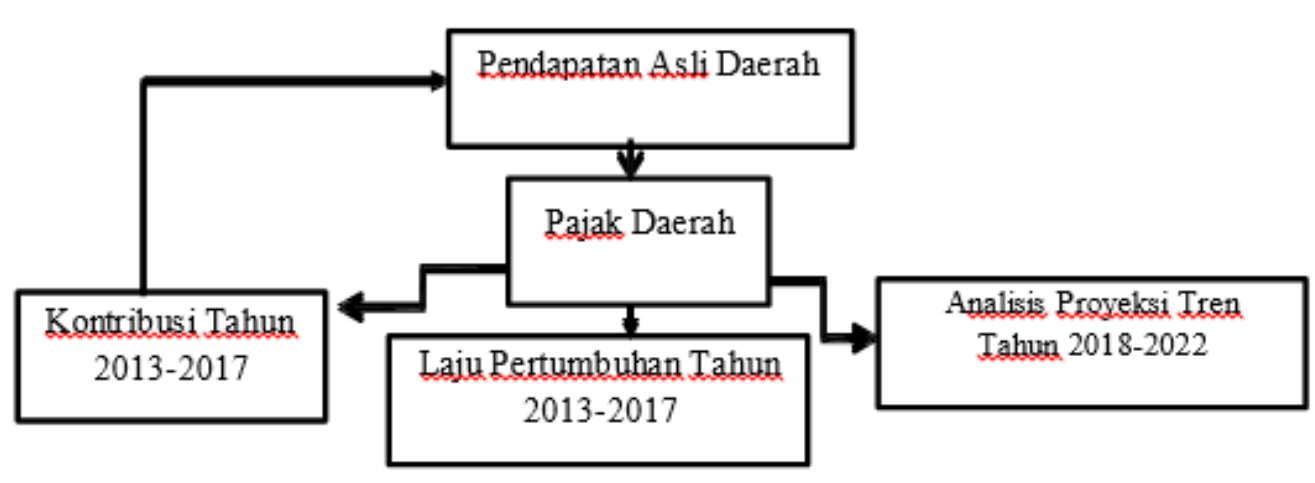

Gambar 1. Kerangka Berpikir 


\section{Metode Penelitian}

\section{Rancangan Penelitian}

Metode penelitian yang digunakan dalam penelitian ini adalah metode penelitian deskriptif dengan pendekatan kuantitatif untuk mendapatkan gambaran lebih jelas dan terperinci mengenai suatu keadaan berdasarkan data atau informasi yang telah didapatkan.

Sampel

Sampel adalah bagian dari jumlah dan karakteristik yang dimiliki oleh populasi yang akan diteliti. Bila populasi besar, peneliti tidak mungkin mempelajari semua yang ada pada populasi, misalnya karena keterbatasan dana, tenaga dan waktu, maka peneliti dapat menggunakan sampel yang diambil dari populasi itu. Untuk itu sampel yang diambil dari populasi harus betu-betul representatif (Sugiyono, $2010: 81$ ). Sedangkan sampel dalam penelitian ini adalah laporan target dan realisasi pajak daerah Kabupaten S ikka periode tahun 2013 hingga 2017.

\section{Teknik Pengumpulan Data}

Menurut S ugiyono (2010:137), pengertian pengumpulan data adalah proses, cara, perbuatan mengumpulkan, atau menghimpun data. Adapun teknik pengumpulan data dalam penelitian ini, yaitu :

1. Wawancara

Wawancara merupakan komunikasi dua arah untuk mendapatkan data dari informan. Kegiatan wawancara dilakukan oleh peneliti dengan pegawai dari Badan Pendapatan Daerah Kabupaten S ikka.

2. Dokumentasi

Dokumentasi merupakan pengumpulan data yang dibutuhkan dengan mengumpulkan langsung dari Badan Pendapatan Daerah Kabupaten S ikka.

\section{Studi Kepustakaan}

Studi Kepustakaan dalam penelitian ini yaitu dengan mengumpulkan informasi yang berkaitan dengan topik penelitian ini seperti buku, jurnal, skripsi dan sumber-sumber lainnya 


\section{Analisis Data}

Analisis Kontribusi menurut Halim dalam Syafitri (2016), analisis kontribusi yaitu suatu anaslisis yang digunakan untuk mengetahui seberapa besar kontribusi dapat disumbangkan dari penerimaan terhadap anggaran. Penggunaan analisis ini untuk mengetahui seberapa besar kontribusi terhadap PAD.

$$
\text { Analisis Kontribusi }=\frac{\text { Realisasi Pajak Daerah }}{\text { Realisasi Penerimaan PAD }} \times 100 \%
$$

Tabel 3 Kriteria Kontribusi

\begin{tabular}{|c|c|}
\hline Presentase Kontribusi & Krite ria \\
\hline$\geq 50 \%$ & Sangat baik \\
\hline $40 \%-50 \%$ & Baik \\
\hline $30 \%-40 \%$ & Sedang \\
\hline $20 \%-30 \%$ & Cukup \\
\hline $10 \%-20 \%$ & Kurang \\
\hline$\leq 10 \%$ & Sangat kurang \\
\hline
\end{tabular}

Sumber : Halim dalam Syafitri (2016)

\section{Analisis Laju Pertumbuhan}

Menurut Halim dalam Syafitri (2016), laju pertumbuhan pajak daerah merupakan selisih realisasi penerimaan pajak daerah pada tahun tertentu dengan realisasi penerimaan pajak daerah tahun sebelumnya dibagi dengan realisasi penerimaan pajak daerah pada tahun sebelumnya. Untuk menghitung laju pertumbuhan pajak daerah digunakan rumus sebagai berikut:

$$
\omega=\frac{x_{t}-1}{x(t-1)} \omega 100 \%
$$

Keterangan:

Gx : Pertumbuhan pajak daerah per tahun

Xt : Realisasi pajak daerah tahun tertentu

$\mathrm{X}(\mathrm{t}-1)$ : Realisasi penerimaan pajak daerah tahun sebelumnya 
Tabel 4. Kriteria Laju Pertumbuhan

\begin{tabular}{|c|c|}
\hline Presentase & Krite ria \\
\hline $85-100 \%$ & Sangat berhasil \\
\hline $70-85 \%$ & Berhasil \\
\hline $55-70 \%$ & Cukup berhasil \\
\hline $30-50 \%$ & Kurang berhasil \\
\hline$\leq 30 \%$ & Tidak berhasil \\
\hline
\end{tabular}

\section{Analisis Proyeksi Penerimaan Pajak Daerah}

Untuk menghitung besarnya prediksi/proyeksi penerimaan pajak daerah terhadap pendapatan asli daerah Kabupaten S ikka periode tahun 2018 sampai dengan tahun 2022, dilakukan dengan metode peramalan Trend Least Squere (Dewi : 2010). Dapat dirumuskan sebagai berikut :

$$
\mathrm{Y}=\mathrm{a}+\mathrm{bx}
$$

Keterangan :

$$
\begin{array}{ll}
\mathrm{Y} & =\text { nilai yang diproyeksikan } \\
\mathrm{X} & =\text { interval waktu } \\
\mathrm{a} & =\text { konstanta } \\
\mathrm{b} & =\text { gradien atau koefisien arah garis }
\end{array}
$$

Nilai a dan b dapat dihitung dengan rumus sebagai berikut

$$
\mathrm{a}={ }_{\mathrm{n}}^{\sum \mathrm{Y}} \mathrm{n} \quad \text { dan } \mathrm{b}=\frac{\sum \mathrm{XY}}{\sum \mathrm{X}^{2}}
$$

Keterangan :

$\Sigma \mathrm{Y} \quad=$ jumlah penerimaan pajak

$\mathrm{n} \quad=$ jumlah data

$\Sigma X Y=$ jumlah penerimaan pajak dikalikan interval waktu

$\Sigma X^{2}=$ jumlah interval waktu yang dikuadratkan 


\section{Hasil dan Pe mbahasan}

\subsection{Hasil}

\section{Analisis Kontribusi Pajak Daerah Terhadap Pendapatan Asli Daerah}

\section{Kabupate n Sikka Tahun 2013-2017}

Pajak daerah mempunyai peranan penting dalam penerimaan pendapatan asli daerah. Hal ini disebabkan karena pajak daerah merupakan bagian dari pendapatan asli daerah. Untuk mengetahui seberapa besar kontribusi pajak daerah terhadap pendapatan asli daerah Kabupaten S ikka dari tahun 2013-2017 dapat dihitung dengan rumus analisis kontribusi. Analisis ini digunakan untuk mengetahui kontribusi pajak daerah terhadap pendapata $\mathrm{n}$ asli daerah yang dihitung dengan rumus sebagai berikut:

$$
\text { Analisis Kontribusi }=\frac{\text { Realisasi Pajak Daerah }}{\text { Realisasi Penerimaan PAD }} \times 100 \%
$$

Setelah menganalisis kontribusi pajak daerah terhadap pendapatan asli daerah, langkah berikutnya yaitu menentukan kriterianya berdasarkan hasil perhitungan tersebut. Berikut merupakan tabel kriteria kontribusi pajak daerah terhadap pendapatan asli daerah.

Tabel 5. Kriteria Kontribusi

\begin{tabular}{|c|c|}
\hline Presentase Kontribusi & Krite ria \\
\hline$\geq 50 \%$ & Sangat baik \\
\hline $40 \%-50 \%$ & Baik \\
\hline $30 \%-40 \%$ & Sedang \\
\hline $20 \%-30 \%$ & Cukup \\
\hline $10 \%-20 \%$ & Kurang \\
\hline$\leq 10 \%$ & Sangat kurang \\
\hline
\end{tabular}

Sumber : Halim dalam Syafitri (2016)

Berikut merupakan perhitungan kontribusi pajak daerah terhadap pendapatan asli daerah Kabupaten Sikka dari tahun 2013-2017. 
1) Tahun 2013

$$
\begin{aligned}
\text { Analisis Kontribusi } & =\frac{8.526 .092 .732 .00}{50.257 .084 .172 .90} \times 100 \% \\
& =16,96 \%
\end{aligned}
$$

2) Tahun 2014

$$
\begin{aligned}
\text { Analisis Kontribusi } & =\frac{9.511 .660 .055 .55}{78.356 .674 .459 .86} \times 100 \% \\
& =12,14 \%
\end{aligned}
$$

3) Tahun 2015

$$
\begin{aligned}
\text { Analisis Kontribusi } & =\frac{11.608 .213 .126 .00}{78.096 .258 .303 . .50} \times 100 \% \\
& =14,86 \%
\end{aligned}
$$

4) Tahun 2016

$$
\begin{aligned}
\text { Analisis Kontribusi } & =\frac{11.624 .926 .899 .00}{80.269 .749 .570 .99} \times 100 \% \\
& =14,48 \%
\end{aligned}
$$

\begin{tabular}{|c|c|c|c|c|}
\hline Tahun & $\begin{array}{c}\text { Realisasi Pajak } \\
\text { Daerah }\end{array}$ & $\begin{array}{c}\text { Realisasi } \\
\text { Pendapatan Asli } \\
\text { Daerah }\end{array}$ & Kontribusi & Krite ria \\
\hline 2013 & 8.526 .091 .731 .00 & 50.257 .084 .172 .90 & $16,96 \%$ & Kurang \\
\hline 2014 & 9.511 .660 .055 .55 & 78.356 .674 .459 .86 & $12,14 \%$ & Kurang \\
\hline 2015 & 11.608 .213 .126 .00 & $78.096 .258 .303 . .50$ & $14,86 \%$ & Kurang \\
\hline 2016 & 11.624 .926 .899 .00 & 80.269 .749 .570 .99 & $14,48 \%$ & Kurang \\
\hline 2017 & 15.235 .535 .867 .00 & 118.176 .975 .236 .17 & $12,89 \%$ & Kurang \\
\hline Rata-Rata & & & $14,27 \%$ & Kurang \\
\hline
\end{tabular}

5) Tahun 2017

$$
\text { Analisis Kontribusi }=\frac{15.235 .535 .867 .00}{118.176 .975 .236 .17} \times 100 \%
$$

Berdasarkan perhitungan yang telah dilakukan diatas, hasilnya dapat dilihat pada tabel dibawah ini.

Tabel 6. Kontribusi pajak daerah Kabupaten Sikka tahun 2013-2017

Sumber: Data sekunder diolah 
Kontribusi pajak daerah terhadap pendapatan asli daerah tahun 2013 sebesar 16,96\%. Pada tahun 2014 kontribusinya sebesar 12,14\%, turun sebesar 4,82\% dari tahun 2013. Kontribusi pajak daerah pada tahun 2015 sebesar 14,86\% naik 2,72\% dari tahun sebelumnya. Sedangkan, tahun 2016 kontribusinya sebesar 14,48\% turun sebesar 0,38\% dari tahun sebelumnya. Kontribusi pajak daerah pada tahun 2017 sebesar $12,89 \%$, mengalami penurunan $1,59 \%$

Rata-rata kontribusi pajak daerah terhadap pendapatan asli daerah Kabupaten Sikka dari tahun 2013-2017 (5 tahun) sebesar 14,27\%. Kontribusi terkecil terjadi pada tahun 2014 yaitu sebesar 12,14\%, sedangkan kontribusi terbesar terjadi pada tahun 2013 yaitu sebesar 16,96\%. Dengan demikian hasil ini menunjukan bahwa, pajak daerah selama lima tahun terakhir kurang berkontribusi terhadap pendaptan asli daerah Kabupaten Sikka. Guna lebih jelasnya, besar persentase kontribusi pajak daerah terhadap pendapatan asli daerah Kabupaten Sikka pada tahun 2013 hingga tahun 2017 dapat dilihat dalam diagram berikut:

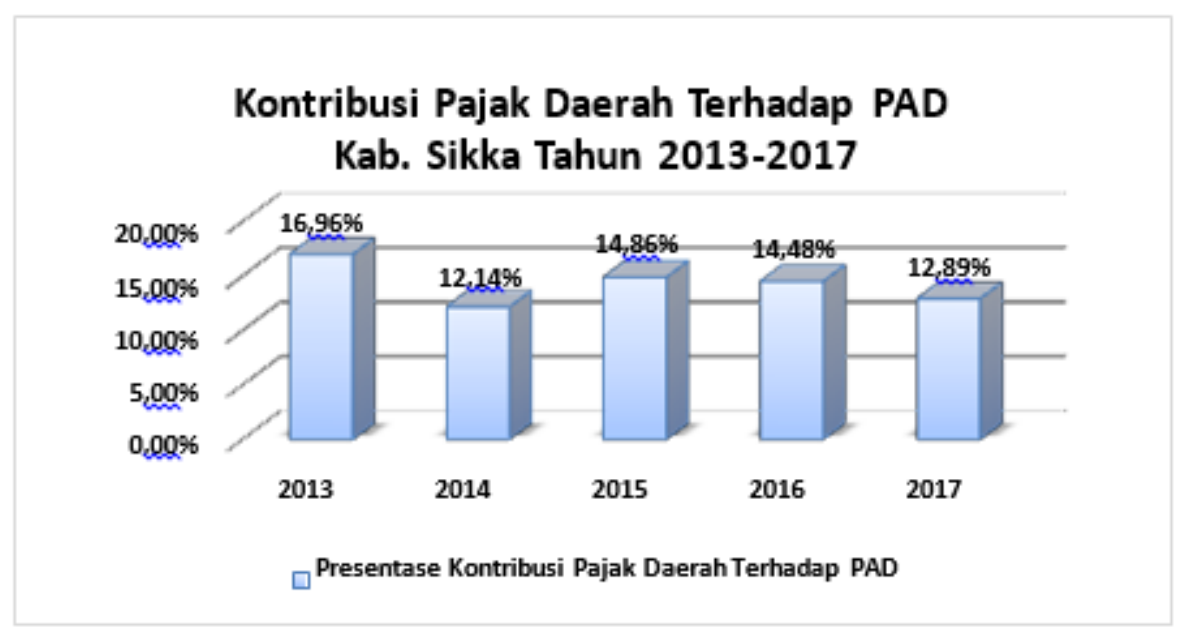

Gambar 2. Analisis Laju Pertumbuhan Pajak Daerah Kabupaten Sikka

Menurut Halim dalam Syafitri (2016), laju pertumbuhan pajak daerah merupakan selisih realisasi penerimaan pajak daerah pada tahun tertentu dengan realisasi penerimaan pajak daerah tahun sebelumnya dibagi dengan realisasi penerimaan pajak daerah pada tahun sebelumnya. Untuk menghitung laju pertumbuhan pajak daerah digunakan rumus sebagai berikut: 


$$
\omega=\frac{X+1-1)}{x(t-1)} \omega 100 \%
$$

Keterangan:

Gx : Pertumbuhan pajak daerah per tahu

$\mathrm{Xt} \quad$ : Realisasi pajak daerah tahun tertentu

$\mathrm{X}(\mathrm{t}-1)$ : Realisasi penerimaan pajak daerah tahun sebelumnya

Setelah menganalisis laju pertumbuhan pajak daerah, langkah berikutnya yaitu menentukan kriterianya berdasarkan hasil perhitungan tersebut. Berikut merupakan tabel kriteria laju pertumbuhan pajak daerah.

Tabel 7 kriteria laju pertumbuhan

\begin{tabular}{|c|c|}
\hline Presentase & Krite ria \\
\hline $85-100 \%$ & Sangat berhasil \\
\hline $70-85 \%$ & Berhasil \\
\hline $55-70 \%$ & Cukup berhasil \\
\hline $30-50 \%$ & Kurang berhasil \\
\hline$\leq 30 \%$ & Tidak berhasil \\
\hline
\end{tabular}

Sumber : Halim dalam Syafitri, 2016

Berikut merupakan perhitungan analisis laju pertumbuhan pajak daerah terhadap pendapatan asli daerah Kabupaten Sikka tahun 2013-2017. 
1) Tahun 2014

$$
\begin{gathered}
\frac{9.511 .660 .055 .55-8.526 .091 .731 .00}{8.526 .091 .731 .00} 100 \% \\
=11,56 \%
\end{gathered}
$$

2) Tahun 2015

$$
\begin{aligned}
& =\frac{11.608 .213 .126 .00-9.511 .660 .055 .55}{9.511 .660 .055 .55} 100 \% \\
& =22,04 \%
\end{aligned}
$$

3) Tahun 2016

$$
\begin{aligned}
& =\frac{11.624 .926 .899 .00-11.608 .213 .126 .00}{11.608 .213 .126 .00} 100 \% \\
& =0,14 \%
\end{aligned}
$$

4) Tahun 2017

$$
\begin{aligned}
& =\frac{15.235 .535 .867 .00-11.624 .926 .899 .00}{11.624 .926 .899 .00} 00 \% \\
& \mathrm{Gx}=31,06 \%
\end{aligned}
$$

Berdasarkan perhitungan yang telah dilakukan diatas, hasilnya dapat dilihat pada tabel dibawah ini.

Tabel 8 Laju Pertumbuhan Pajak Daerah Kabupaten Sikka Tahun 2013-2017

\begin{tabular}{|c|c|c|c|}
\hline Tahun & Realisasi Pajak Daerah & Pertumbuhan & Krite ria \\
\hline 2013 & 8.526 .091 .731 .00 & - & - \\
\hline 2014 & 9.511 .660 .055 .55 & $11,56 \%$ & Tidak berhasil \\
\hline 2015 & 11.608 .213 .126 .00 & $22,04 \%$ & Tidak berhasil \\
\hline 2016 & 11.624 .926 .899 .00 & $0,14 \%$ & Tidak berhasil \\
\hline 2017 & 15.235 .535 .867 .00 & $31,06 \%$ & Kurang berhasil \\
\hline Rata-Rata & & $16,2 \%$ & Tidak berhasil \\
\hline
\end{tabular}

Sumber: Data sekunder diolah 
Pertumbuhan pajak daerah Kabupaten S ikka tahun 2014 yaitu sebesar 11,56\%. Pada tahun 2015 pertumbuhannya sebesar 22,04\%, mengalami kenaikan yang cukup signifikan yaitu sebesar 10,48\%. Namun, pada tahun 2016 pertumbuhannya hanya sebesar $0,14 \%$ atau menurun drastis sebesar $21,9 \%$ dari tahun 2015. Tetapi, pajak daerah pada tahun 2017 kemb ali mengalami pertumbuhan yang cukup tinggi yaitu sebesar $31,06 \%$, naik 30,92\% dari tahun sebelumnya. Rata-rata pertumbuhan pajak daerah Kabupaten $\mathrm{S}$ ikka dalam beberapa tahun terakhir sebesar 16,2 \%. Hal ini berarti pertumbuhan pajak daerah Kabupaten Sikka masuk pada kriteria tidak berhasil.Berikut merupakan grafik yang menunjukan laju pertumbuhan pajak daerah Kabupaten Sikka tahun 2013 -2017

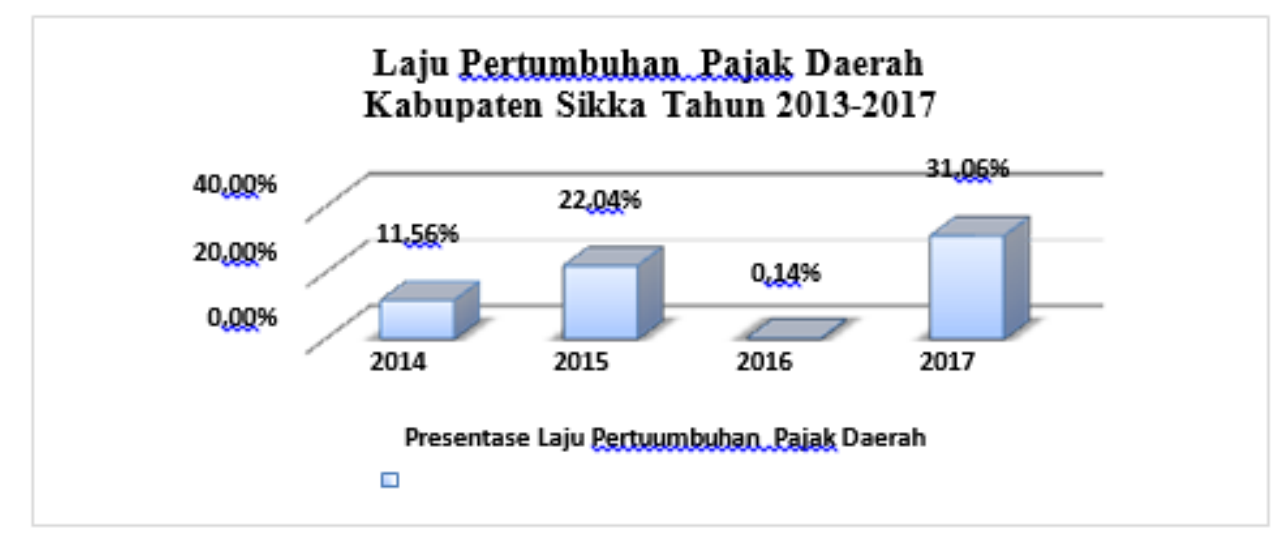

Gambar 3. Analisis Proyeksi Tren Pajak Daerah

Kecenderungan penerimaan Pajak daerah di tahun-tahun mendatang dapat dilihat dengan menggunakan metode estimasi yang salah ssatunya adalah metode kuadrat terkecil (least square) dengan rumus :

$$
\mathrm{Y}=\mathrm{a}+\mathrm{bx}
$$

Keterangan :

$$
\begin{aligned}
\mathrm{Y} & =\text { nilai yang diproyeksikan } \\
\mathrm{X} & =\text { interval waktu } \\
\mathrm{a} & =\text { konstanta } \\
\mathrm{b} & =\text { gradien atau koefisien arah garis }
\end{aligned}
$$


Nilai a dan b dapat dihitung dengan rumus sebagai berikut:

$$
\mathrm{a}=\sum \frac{\mathrm{Y}}{n} \quad \text { dan } \mathrm{b}=\frac{\sum \mathrm{XY}}{\Sigma \mathrm{X}^{2}}
$$

Keterangan :

$\Sigma \mathrm{Y}=$ jumlah penerimaan pajak

$\mathrm{n}=$ jumlah data

$\Sigma \mathrm{XY}=$ jumlah penerimaan pajak dikalikan interval waktu

$\Sigma \mathrm{X}_{2}=$ jumlah interval waktu yang dikuadratkan

Tabel 9 Perhitungan Penerimaan Pajak Daerah

\begin{tabular}{|c|c|c|c|c|}
\hline Tahun & $\mathbf{X}$ & $\mathbf{Y}$ & $\mathbf{X Y}$ & \\
\hline 2013 & -2 & 8.526 .091 .731 .00 & -17.052 .183 .462 & 4 \\
\hline 2014 & -1 & $9.511 .660 .055,55$ & $-9.511 .660 .055,55$ & 1 \\
\hline 2015 & 0 & 11.608 .213 .126 .00 & 0 & 0 \\
\hline 2016 & 1 & 11.624 .926 .899 .00 & 11.624 .926 .899 & 1 \\
\hline 2017 & 2 & 15.235 .535 .867 .00 & 30.471 .071 .734 & 4 \\
\hline Jumlah & 0 & $56.506 .427 .678,55$ & $15.532 .155 .115,45$ & 10 \\
\hline
\end{tabular}


Dari tabel diatas kemudian dicari nilai dari persamaan $\mathrm{Y}=\mathrm{a}+\mathrm{bX}$.

1) Mengitung nilai a

$$
\begin{aligned}
& \mathrm{a}=\frac{\Sigma \mathrm{Y}}{n} \\
& \mathrm{a}=\frac{56.506 .427 .678,55}{5} \\
& \mathrm{a}=11.301 .285 .535,71
\end{aligned}
$$

2) Menghitung nilai $b$

$$
\begin{aligned}
& \mathrm{b}=\frac{\sum \mathrm{XY}}{\sum \mathrm{X}^{2}} \\
& \mathrm{~b}=\frac{15 \cdot 532 \cdot 155 \cdot 115,45}{10} \\
& \mathrm{~b}=1 \cdot 553 \cdot 215 \cdot 511,545
\end{aligned}
$$

Jadi, Y = 11.301.285.535,71 + 1.553.215.511,545 (X). Selanjutnya, dengan mengganti nilai $\mathrm{X}$ diperoleh nilai trendnya sebagai berikut :

1) Tahun 2018

$$
\begin{aligned}
\mathrm{Y} & =11.301 .285 .535,71+1.553 .215 .511,545(\mathrm{X}) \\
& =11.301 .285 .535,71+1.553 .215 .511,545(3) \\
& =15.960 .932 .070,345
\end{aligned}
$$

2) Tahun 2019

$$
\begin{aligned}
\mathrm{Y} & =11.301 .285 .535,71+1.553 \cdot 215.511,545(\mathrm{X}) \\
& =11.301 .285 .535,71+1.553 .215 .511,545(4) \\
& =17.514 .147 .581,89
\end{aligned}
$$

3) Tahun 2020

$$
\begin{aligned}
\mathrm{Y} & =11.301 .285 .535,71+1.553 .215 .511,545(\mathrm{X}) \\
& =11.301 .285 .535,71+1.553 .215 .511,545(5) \\
& =19.067 .363 .093,435
\end{aligned}
$$

4) Tahun 2021

$$
\begin{aligned}
\mathrm{Y} & =11.301 \cdot 285.535,71+1.553 \cdot 215.511,545(\mathrm{X}) \\
& =11.301 \cdot 285.535,71+1.553 \cdot 215.511,545(6) \\
& =20.620 .578 .604,98
\end{aligned}
$$

5) Tahun 2022

$$
\mathrm{Y}=11.301 .285 .535,71+1.553 .215 .511,545(\mathrm{X})
$$




$$
\begin{aligned}
& =11.301 .285 .535,71+1.553 \cdot 215.511,545(7) \\
& =22.173 .794 .116,525
\end{aligned}
$$

Hasil perhitungan analisis Tren Pajak Daerah Kabupaten S ikka tahun 2018 -2022 dapat dilihat di Tabel 10 berikut.

Tabel 10. Hasil Perhitungan Analisis Tren Proyeksi Pajak Daerah

\begin{tabular}{|c|c|c|}
\hline No & Estimasi Tahun & $\begin{array}{c}\text { Proyeksi Penerimaan } \\
\text { Pajak Daerah (Rp) }\end{array}$ \\
\hline 1 & 2018 & $15.960 .932 .070,345$ \\
\hline 2 & 2019 & $17.514 .147 .581,89$ \\
\hline 3 & 2020 & $19.067 .363 .093,435$ \\
\hline 4 & 2021 & $20.620 .578 .604,98$ \\
\hline 5 & 2022 & $22.173 .794 .116,525$ \\
\hline
\end{tabular}

Sumber: Data sekunder diolah

Berikut merupakan grafik yang menunjukan laju pertumbuhan pajak daerah Kabupaten S ikka tahun 2013-2017.

\section{Proyeksi Tren Penerimaan Pajak Daerah Kabupaten Sikka Tahun 2018-2022}

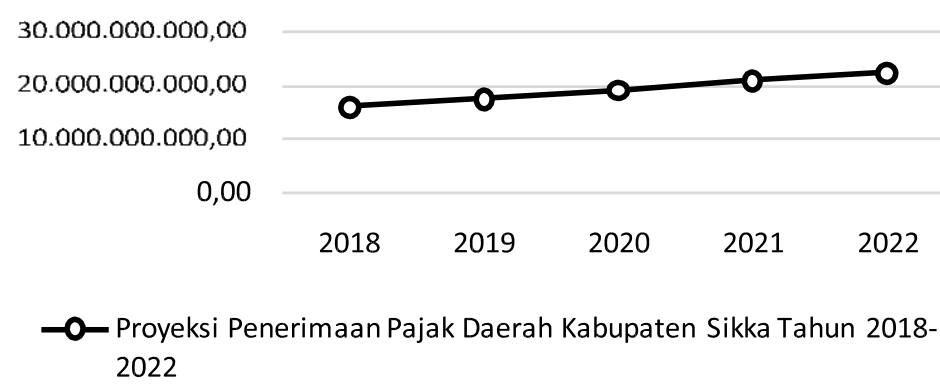

0,00

$2018 \quad 2019 \quad 2020 \quad 2021 \quad 2022$

- - Proyeksi Penerimaan Pajak Daerah Kabupaten Sikka Tahun 20182022

Sumber: Data diolah

Gambar 4. Proyeksi Tren Penerimaan Pajak daerah Kab. Sikka 


\subsection{Pembahasan}

\section{Kontribusi Pajak Daerah Terhadap PAD Kabupaten S ikka Tahun 2013-} 2017

Hasil analisis data menunjukan bahwa, pajak daerah tergolong dalam kriteria kurang berkontribusi terhadap penerimaan pendapatan asli daerah Kabupaten S ikka dari tahun 2013 hingga tahun 2017. Rata-rata kontribusi pajak daerah terhadap pendapatan asli daerah sebe sar 14,27\%. Melihat fenomena ini pihak pemungut pajak sangat diharapkan untuk mengupayakan optimalisasi potensi pajak daerah Kabupaten S ikka di masa yang akan datang.

Kurangnya tingkat kontribusi pajak daerah terhadap pendapatan asli daerah Kabupaten S ikka disebabkan karena adanya faktor-faktor penghambat dalam pemungutan pajak daerah. Faktor- faktor tersebut antara lain adanya wajib pajak yang tidak patuh dalam membayar pajak daerah, adanya wajib pajak yang tidak melaporkan omset yang sebenarnya, kurangnya kesempatan untuk melakukan sosialisasi kepada masyarakat berkaitan dengan pengelolaan pendapatan asli daerah, kurangnya kompetensi sumber daya aparatur pemungut pajak, adanya calon wajib pajak baru yang belum terdaftar dan kurangnya pengawasan dari para pemungut pajak daerah. Rahayu (2013:27) menyebutkan bahwa faktor-faktor yang mempengaruhi penerimaan pajak antara lain:

1) Kejelasan, kepastian dan kesederhanaan peraturan perpajakan

2) Sistem administrasi perpajakan yang tepat

3) Kualitas pelayanan wajib pajak

4) Kualitas sumber daya manusia pemungut pajak

5) Kesadaran dan pemahaman wajib pajak.

Hasil penelitian ini sejalan dengan penelitian yang dilakukan Prasetio (2014) dengan judul analisis kontribusi pajak daerah terhadap pendapatan asli daerah Kabupaten Gunung K idul. Dimana hasil penelitiannya menunjukan bahwa kontribusi pajak daerah terhadap pendapatan asli daerah Kabupaten Gunung K idul berada pada kriteria kurang berkontribusi dan masih bisa diupayakan peningkatannya. 


\section{Laju Pertumbuhan Pajak Daerah Kabupaten S ikka Tahun 2013-2017}

Berdasarkan hasil analisis data menunjukan bahwa, laju pertumbuhan pajak daerah Kabupaten Sikka tahun 2013 hingga tahun 2017 tergolong dalam kriteria tidak berhasil. Presentase pertumbuhan pajak daerah Kabupaten S ikka yang tertinggi terjadi pada tahun 2017 sebesar 31,06\% dan pertumbuhan paling rendah pada tahun 2016 sebesar $0,14 \%$ dengan rata-rata pertumbuhan selama 5 tahun sebesar 16,2\%. Melihat kondisi tersebut pemerintah daerah diharapkan untuk mengoptimalkan pajak daerah karena pajak daerah merupakan salah satu sumber pendapatan asli daerah yang dapat dioptimalkan.Hasil penelitian ini sejalan dengan penelitian yang dilakukan Prasetio (2014) dengan judul analisis kontribusi pajak daerah terhadap pendapatan asli daerah Kabupaten Gunung K idu 1. Dimana hasil penelitiannya menunjukan bahwa laju pertumbuhan pajak daerah Kabupaten Gunung K idul tahun 2006-2012 berada pada kriteria tidak berhasil dan pertumbuhannya terlihat fluktuatif.

\section{Proyeksi Trend Penerimaan Pajak Daerah Kabupaten Sikka Tahun 2018-}

\section{2}

Berdasarkan hasil perhitungan yang telah dilakukan dengan menggunakan metode kuadrat terkecil (least square method) diperoleh persamaan

$$
\mathrm{Y}=11.301 .285 .535,71+1.553 .215 .511,545(\mathrm{X}) \text {. }
$$

Penerimaan pajak daerah selama lima tahun kedepan yakni tahun 2018-2022 diproyeksikan terus meningkat seperti pada hasil perhitungan sebelumnya. Pada tahun 2018 proyeksi penerimaan pajak daerah Kabupaten Sikka sebesar Rp 15.960.932.070,345. Pada tahun 2019 proyeksi penerimaan pajak daerah sebesar Rp 17.514.147.581,89 da n pada tahun 2020 penerimaan pajak daerah diproyeksikan sebesar Rp 19.067.363.093,435. Prediksi pajak daerah Kabupaten S ikka pada tahun 2021 sebesar Rp 20.620.578.604,98, sedangkan pada tahun 2022 penerimaan pajak daerah Kabupaten Sikka diproyeksikan sebesar Rp 22.173.794.116,525. 


\section{Kesimpulan}

Berdasarkan hasil analisis data dan pembahasan yang telah dilakukan pada bab sebelumnya dapat ditarik kesimpulan sebagai berikut:

1. Rata-rata kontribusi pajak daerah terhadap pendapatan asli daerah Kabupaten Sikka dari tahun 2013-2017 (5 tahun) sebesar 14,27\%. Hasil ini menunjukan bahwa tingkat Kontribusi pajak daerah terhadap pendapatan asli daerah Kabupaten Sikka dari tahun 2013-2017 masuk dalam kriteria kurang berkontribusi terhadap pendapatan asli daerah.

2. Rata-rata laju pertumbuhan pajak daerah Kabupaten Sikka tahun 20132017 yaitu sebesar 16,2\%. Hal ini menunjukan bahswa pertumbuhan pajak daerah Kabupaten Sikka masuk dalam kriter ia kurang berhasil.

3. Hasil perhitungan proyeksi penerimaan pajak daerah selama lima tahun kedepan yakni tahun 2018-2022 diperkirakan akan terus meningkat setiap tahunnya. Pada tahun 2018 prediksi penerimaan pajak daerah Kabupaten Sikka sebesar Rp 15.960.932.070,345. Pada tahun 2019 prediksi penerimaan pajak daerah sebesar Rp 17.514.147.581,89 dan pada tahun 2020 penerimaan pajak daerah diprediksikan sebesar Rp 19.067.363.093,435. P rediksi pajak daerah Kabupaten S ikka pada tahun 2021 sebesar Rp 20.620.578.604,98, sedangkan pada tahun 2022 penerimaan pajak daerah Kabupaten Sikka diprediksikan sebesar Rp 22.173.794.116,525.

Dari kesimpulan diatas, maka dalam rangka untuk meningkatkan pendapatan asli daerah khususnya dari sektor pajak daerah disarankan hal- hal sebagai berikut:

1. Pemerintah Daerah Kabupaten S ikka perlu mengadakan pelatihan kepada para pemungut pajak dan meningkatkan sistem pengawasan terhadap wajib pajak agar peningkatan pendapatan asli daerah dapat terealisasi. 
2. Melakukan pendataan terhadap objek-objek pajak daerah yang baru (ekstensifikasi) dan upaya intensifikasi pajak daerah berdasarkan potensi riil yang dimiliki.

3. Masyrakat perlu diberikan sosialisasi dan pandangan tentang pentingnya kesadaran dan tanggungjawab masyarakat dalam pembayaran pajak da erah. Karena hal ini masyarakat merupakan subjek pajak daerah yang pada dasarnya merupakan faktor penunjang tercapainya peningkatan pendapatan asli daerah khususnya dari sektor pajak daerah

Dari hasil perhitungan proyeksi trend penerimaan pajak daerah diatas, Pemerintah Kabupaten Sikka diharapkan lebih baik lagi dalam memaksimalkan potensi-potensi pajak daerah yang terdapat di wilayah kabupaten ini.

\section{DAFTAR PUSTAKA}

Anggoro, Damas. 2017. Pajak Daerah dan Retribusi Daerah. Malang: UB Press. Dewi, Kristina Ratih P uspa. 2010. Analisis Kontribusi Pajak Hotel dan Restoran Terhadap Pendapatan Asli Daerah (Studi kasus di Pemerintah Kota Yogyakarta). Skripsi. Program Studi Akuntansi, Fakultas Ekonomi, Universitas Sanata Dharma Yogyakarta.

Kamangi, Cornelin G., Sondakh, Jullie J., Runtu, Tressje. 2016. Analisis Kontribusi Pajak Daerah Terhadap Pendapatan Asli Daerah (PAD) di Kabupaten Minahasa Utara Dan Kabupaten Minahasa Tenggara (Periode 2011-2015). Jurnal Berkala Ilmiah Efisiensi. Vol. 16, No. 4.

Peraturan Daerah Kabupaten Sikka Nomor 2 Tahun 2011 tentang Bea Perolehan Hak Atas Tanah dan Bangunan.

Peraturan Daerah Kabupaten S ikka Nomor 10 Tahun 2011 tentang Pajak Daerah. Peraturan Daerah Nomor 8 Tahun 2012 tentang Pajak Bumi dan Bangunan Perdesaan dan Perkotaan.

Prasetyo, Papang Permadi. 2014. Analisis Kontribusi Pajak Daerah Terhadap 
Pendapatan Asli Daerah Kabupaten Gunung Kidul. Jurnal Kajian Bisnis, Vol. 22, No. 1

Putra, Windhu. 2018. Tata Kelola Ekonomi Keuangan Daerah. Depok: PT. Raja Grafindo Persada.

Rahayu, S iti Kurnia. 2013. Perpajakan Indonesia: Teori dan Teknis Perhitungan. Yogyakarta: Graha Ilmu.

Roy, Fredi De dan Budiarso, Novi. 2015 Analisis Kontribusi Penerimaan Pajak Daerah Terhadap Pendapatan Asli Daerah (PAD) di Kabupaten Raja Ampat. Jurnal EMBA, Vol.3 No.4.

Siregar, Baldric. 2015. Akuntansi Sektor Publik . Yogyakarta: UPP-STIM

YKPN. Sugiyono. 2010. Metode Penelitian Kuantitatif dan Kualitatif dan $R$ \& $D$. Bandung: Alfabeta

Syafitri, Dhyni Inka. 2016. Analisisi Pertumbuhan dan Kontribusi Pajak Daerah, Retribusi Daerah, dan Lain -lain PAD yang Sah Terhadap PA D (Studi Pada Kabupaten/kota di Provinsi Jawa Tengah). Skripsi. Program Studi Akuntansi, Fakultas Ekonomi dan Bisnis, Universitas Muhammadyah Surakarta.

Undang-Undang Republik Indonesia Nomor 33 Tahun 2004 tentang Perimbangan Keuangan Antara Pemerintah Pusat dan Pemerintahan Daerah.

Undang-Undang Republik Indonesia Nomor 28 Tahun 2009 tentang Pajak Daerah dan Retribusi Daerah.

Undang-Undang Republik Indonesia Nomor 23 Tahun 2014 tentang Pemerintahan Daerah.

Utami, Mulyana dan N ingsih, E. S urasety. 2018. Analisis Efektivitas dan Kontribusi Penerimaan Pajak dan Retribusi Daerah Terhadap Pendapatan Asli Daerah Kabupaten/Kota di Provinsi Aceh Tahun 2011 -2015. Jurnal Ilmiah Mahasiswa Ekonomi Akuntansi (JIMEKA) Vol. 3, No.4. 